\title{
Reproduction Beyond Hu/Man Extinction: Detoxifying Care in Latin American Anthropocene Fictions
}

\author{
Allison Eleanor Mackey 1,2*
}

Published: March 5, 2021

\begin{abstract}
Anxieties around failed parenting are linked to humanity's failed stewardship of the planet in many recent Anthropocene narratives, yet the figure of the biological human child, as *the* signifier of futurity draws attention to the difficulty of imagining the future in non-heteronormative, non-Western, and nonanthropocentric terms. Reproduction is nothing if not a replication of self, of forms of life that are like us. In order to recuperate an alternative model of care from its anthropocentric lineage, I examine how Anacristina Rossi's feminist sci-fi story 'Abel' and Samantha Schweblin's gothic horror novella Distancia de Rescate (2014) perform radical critiques of the idea of reproductive bodies, while at the same time opening out to signal non-binary possibilities of life, offering species-level critique while at the same time remaining rooted in local geographies. These stories embrace the negative implications of Anthropocene thinking, challenging, reflecting, and perpetuating anxieties around sexual difference and the possibility of human extinction, without relying on essentialised mandates about femininity, childbearing and care giving. They engage with what Claire Colebrook calls 'figural extinction' as a way to signal the possibility of moving away from historically toxic androcentric, capitalist and anthropocentric visions of care, and toward an ethic of non/human connection.
\end{abstract}

Keywords: Anthropocene narratives, feminist posthumanism, materialist eco-criticism, gender and extinction, Latin American eco-fiction

[T] he event that will ultimately precipitate human extinction is not its radical openness to dissolution but its suicidal self-enclosure, its self-bounded integrity that will allow it only to imagine its own world from its own imaginative horizon. Claire Colebrook, 'Sexual Indifference' (n.p.)

I thought of Noah but then I laughed, this wasn't Genesis, it was climate change. Anacristina Rossi, 'Abel' (n.p.)

In this article, I examine how 'failed' human reproduction is figured in order to engage with 'the disastrous planetary consequences of our species and the violent rule of sovereign Anthropos' (Braidotti, 2013: 10) in contemporary examples of Latin American Anthropocene fictions: Anacristina Rossi's short story 'Abel,' and Samantha Schweblin's novella Distancia de Rescate. ${ }^{1}$ Comparing them alongside posthumanist, feminist materialist

${ }^{1}$ I borrow Adam Trexler's useful term 'Anthropocene fictions' in order to describe these works, understanding it not only in a temporal sense (i.e. texts published since the turn of the millennium), but also to signal a certain (self-) awareness in such narratives about anthropogenic impacts on the environment. Focusing specifically on the novel, Trexler's central aim is to establish 'how climate change and all its things have changed the capacities of recent literature' (2015: 13). In other words, Anthropocene fictions are not only about the Anthropocene, but they are also of the Anthropocene. 
and material ecocritical thinkers, I analyse how these narratives figure reproduction without generation as a rethinking of relations of body and production, as well as commenting on post-human futures. Pinpointing the way both texts posit non-human nature as an 'agential force that actively participates in the material-discursive configuration of the world with far-reaching political, ethical, and ecological implications,' I aim to participate in a critical project that expands the 'horizons of Latin American environmental critique by engaging with texts not often included in ecocritical debates' (Coleman, 2016: 697). I emphasise how they perform a radical critique of the anthropocentric priority of reproductive bodies in the contemporary moment, and open out to embrace nonbinary understandings of multispecies becoming(s). As Serenella Iovino and Serpil Oppermann put it, this includes the vital materiality of life, experiences of nonhuman entities, and our bodily intra-actions with all forms of material agency as effective actors' (2012: 88). This revaluation sparks a suspension of anthropocentric concepts as the acts of sex, reproduction and traditional notions of care are put into question in ways that move beyond Cartesian logics, and toward what Karen Barad (2003) calls 'intra-active' relations, where the presumed primacy of the human is undermined.

Simply put, to engage in childrearing is to participate in reproducing the future of humanity. Yet US congresswoman Alexandria Ocasio-Cortez's Instagram post last year, in which she asks whether, since 'there's a scientific consensus that the lives of children are going to be very difficult (...) is it still ok to have children?' meshes with the recent formation of voluntary anti-procreation organisations (BirthStrike, for example) for men and women who have decided not to have children in response to climate change, in a 'radical acknowledgment' of how this looming existential threat is already 'altering the way we imagine our future' (Hunt, 2019: n.p.). This anxiety about having children in the face of 'climate breakdown and civilization collapse' (Hunt, 2019: n.p.) also resonates in a long list of Anthropocene fictions that have been emerging in the Anglosphere in recent years. In an increasing proliferation of stories featuring eviscerated family units, abandoned children, pregnancy and child rearing in a time of climate collapse, a sense of impending doom around the notion of failed parenting is increasingly linked to humanity's failed stewardship of the planet. ${ }^{2}$ Adeline Johns-Putra identifies how the presumption in such narratives is that, in order to counter humanity's 'collective hubris,' the only 'way forward' for humanity relies on a notion of care for the environment that is understood largely in terms of inter-generational culpability (2014: 128). Narrative concerns focused on the 'figure of the child,' as a 'primal subject of protection, shelter, and guardianship,' resonate with 'contemporary anxieties about whether we are doing enough to protect, shelter, and safeguard that for which we are responsible' (Johns-Putra, 2016: 523). As the Greta Thunberg and the 'Fridays for Future' phenomenon have made clear, inter-generational reckonings of guilt for the ruined world that our children have inherited has become a crucial part of the narratives we tell ourselves about (the very possibility of) futurity.

As Lee Edelman pointed out in his seminal book No Future, 'we are no more able to conceive of a politics without a fantasy of the future than we are able to conceive of a future without the figure of the Child' (2004: 11). Yet as Edelman's critique of 'reproductive futurism' elucidates, the normative figure of the biological human child, as signifier of futurity par excellence, not only draws attention to the difficulty of imagining the future in nonheteronormative and non-Western terms, but it also speaks to the gendered and essentialist ways that reproductive care is inevitably associated with (mother) nature. ${ }^{3}$ Moreover, what is being mourned in many post-apocalyptic or 'Cli-Fi' (climate fiction) imaginings of the end of the world is, as Johns-Putra suggests, 'the loss of human rather than nonhuman nature' (2016: 521). Cultural theorist Claire Colebrook points out how contemporary anxieties around the 'extinction of sexual difference - both sexuality's necessary relation to extinction and the possibility of sexual difference itself becoming extinct' - have 'seemed to provoke a return or retreat to the figure of the sexual couple' in popular culture (2012: 168). Judging from much of the cultural production of the last few years, even though 'many species already reproduce without dual sexual reproduction, or via sexual reproduction that does not generate distinct sexes' (Colebrook, 2012: 168), it seems that our very notion of the future hinges solely on the sexual reproduction of the human species.

Reproduction is nothing if not a replication of self, of forms of life that are like us. Trapped within normative logics of self-replication even as we endlessly imagine our own end in a myriad of generic forms, we remain unable to valorise forms of life that are radically not like us; we are unable to get our heads around our kinship with, and

\footnotetext{
2 Anxieties around the (im)possibility of parenting in the Anthropocene reverberate in novels such as Weather (2020) by Jenny Offill; Sealed (2017) by Naomi Booth; The End We Start From (2017) by Megan Hunter; Clade (2015) by James Bradley; The New Wilderness (2020) by Diane Cook; The World Without Us (2015) by Mireille Juchau; The History of Bees (2015) by Maja Lunde; Gold, Fame, Citrus (2015) by Claire Vaye Watkins; Heroes of the Frontier (2016) by Dave Eggers; The Bear by Andrew Krivak (2020), and — particularly scathingly — in Lydia Millet's The Children's Bible (2020).

${ }^{3}$ Films such as Darren Aaronofsky's Mother! (2017) riff on gendered representations of 'Mother Earth,' transforming her from a living mother into a passive female body. In a long list of science fiction films, the retributive agency of the earth is represented as 'revenge' — the earth is a capricious and withholding figure who is indifferent to the well-being of her 'children,' and whose vengeful actions are represented as 'the product of emotion, the result of poorly-constrained female subjectivity, crying out for the rationalized discipline historically associated with occidental notions of maleness’ (Mitchell, 2015: n.p.).
} 
existential dependence on, forms of life that are other, or more, than 'human.' But what would it look like to understand reproduction and relations of care in posthuman terms? Here I am understanding posthumanism in Rosi Braidotti's sense, as a non-reductive critique of humanism and of anthropocentrism, premised ultimately on multiplicity, where a non-universal 'we' is assumed (2013: 9). Similarly, Karen Barad (2003: 808) suggests that posthumanism 'marks an account that calls into question the givenness of the differential categories of "human" and "nonhuman," examining the practices through which these differential boundaries are stabilized and destabilized'. The underlying goal of posthumanist thinking is to shift the epistemological plane from an anthropocentric position that presumes the hegemony of the 'human' (read: self-enclosed, male subject, subsuming everything else under his embodied logocentric being) to a much more fluid, immanent plane of relationality, where the human is merely one relatum among many. In this repositioning, all things (including 'us') gain ontological reality in a relation of radical equality where an outside or superior position (like Anthropos) is no longer tenable.

In order to recuperate an alternative model of care from its anthropocentric lineage, in the rest of this article I will explore how the stories I have chosen to focus on forefront sexual difference and reproduction in order to launch a species-level critique, while at the same time remaining rooted in local geographies. Rossi and Schweblin challenge, reflect, and perpetuate anxieties around sexual difference and the possibility of human extinction without relying on essentialised mandates about femininity, childbearing and care giving. In each text, the safety of the family unit - ostensibly a space of protection — proves to be a dangerous illusion that is literally, as well as figuratively, toxic for the protagonists. More or less hinting at alternatives to normative visions of kinship, each of these narratives highlights the possibility of an ecocentric ethics of care, understood as what Johns-Putra (2016: 129) calls 'a feeling - translated into an ethos — of concern for a consideration of the needs of others, whether human or non-human'. In this way, normative anthropocentric models of care are pushed out of the spotlight, so that an ethics of care can be instead be examined within a multispecies frame.

Neither Rossi nor Schweblin offers a hopeful, recuperative or techno-optimistic ending for their reader. In fact, I suggest that both of these narratives seem to be welcoming reproductive failure and the end of humanity — or at least, the end of a certain version of humanity. Engaging with the idea of 'ends' by registering contemporary environmental anxieties, they at the same time avoid reproducing 'ecophobic' (Estok, 2009) or 'necro-futurist' (Canavan, 2014) endings. Instead, they set the tone for dwelling with what Merola (2018: 32) calls 'Anthropocene anxiety,' an uneasy mélange of melancholy, anger, and resignation that amounts to an 'avowal of the ecounpleasant'. Embracing the negative implications of Anthropocene thinking instead of falling back on a requisite hopefulness, they call for a kind of dethroning of Anthropos, echoing Donna Haraway's call to 'make kin not babies!' (2015: 162).

Anacristina Rossi pushes the idea of extinction to the limit by setting her short story 'Abel' in the very center of Central America after the end of the world. ${ }^{4}$ One of Costa Rica's most important writers, Rossi is best known for her 'ecofeminist testimony' novel, La Loca de Gandoca, which 'counters the logic of patriarchal domination with an ethnic and environmental ethic that considers new forms of relation among human and nonhuman subjects' (Kearns, 2016: 98). In stark contrast of the rich biodiversity portrayed in La Loca de Gandoca, the premise of Rossi's short story 'Abel' takes the contemporary climate crisis to its logical conclusion, pushing humanity to the limit of extinction. Oscillating between first- and third-person narration, the story recounts the experiences of a young woman who is one of the only surviving members of the human species. Through a narrative reconstruction of Lalia's memory, the story of a catastrophic, yet slow, apocalypse unfolds: an uncannily familiar history of shifting imperial powers, a series of climate catastrophes, species extinctions, human adaptations, and a long line of failed techno-scientific fixes, culminates in the end of oxygen and hence the end of virtually all biological life on the planet. Lalia and her family had been living in a research station on the Panama Canal, but unlike her scientist parents, her sister and apparently all other humans on earth, she is the only one who has inexplicably been able to adapt biologically to shifting conditions: she absorbs water through her increasingly porous, amphibian-like skin and is able to survive by eating the buds of a single type of flower that has also adapted to thrive without oxygen.

Lalia witnesses everyone and everything around her die, including the asphyxiated earthworms that she unearths while burying her family. After biding her time at the top of a volcano to allow for the smell from the defunct organic matter to dissipate, Lalia decides to make her way to what was once the capital city, in order to see if she can find any other living 'being' (interestingly, she does not say buman being). Surveying the ruined and halfsubmerged city, she is shocked to encounter another human survivor: her own brother. Abel has returned to the

\footnotetext{
${ }^{4}$ The first in a series of three short stories about a young female protagonist called Lalia, this story was published in a 2013 anthology of Costa Rican science fiction called Lunas en Vez de Sombras y Otros Relatos de Ciencia Ficción. I was unable to obtain a copy of this book but the author was kind enough to send me an (unpaginated) PDF of the story, as well as her other two stories, of which only the last one, 'La Esperada,' has page numbers. All translations are my own.
} 
southern hemisphere, by way of the Bering Strait, after studying the arctic permafrost. ${ }^{5}$ Far from a joyous family reunion, there is a dark undertone to this reencounter, and Lalia recounts in the first person her immediate sense of dread. When her older brother marvels at how she has grown into an attractive young woman, Lalia becomes nauseous. For the first time, she resorts to taking one of the antidepressant pills distributed amongst the population to stave off mass panic at the end of the world. Eager to remove herself from her brother, Lalia barricades herself in the bedroom of a derelict hotel where they are sheltering for the night. In the darkness, she hears someone attempting to enter her room. 'This was bigger than climate change,' she says, convinced that her brother was going to 'force her to reproduce with him.' Before sunrise, Lalia takes a knife from the hotel kitchen and slits her brother's throat while he sleeps, as if he were, as she puts it, an 'animal.' Even though this fratricidal act provokes intense feelings of disgust (it causes her to 'vomit and vomit'), Lalia still insists that she would never reproduce with her brother, 'not even if that was the only way for humanity to continue.' The story ends - somewhat abruptly — with Lalia deliberately choosing extinction by killing her only possible reproductive partner.

Lalia's decision to commit fratricide can also be interpreted as a kind of species suicide since, as Haraway (2007: 18) points out: “"woman's" putative self-defining responsibility to "the species," as this singular and typological female is reduced to her reproductive function'. Even though she is the sole member of what has become an endangered species, Lalia refuses to give in to 'Western norms of the reproductive imperative for women' by challenging the presumption that 'all organisms can and should be made to exercise their reproductive capacities in order to resist extinction' (Mitchell, 2015: n.p.). Instead of instigating a new lineage of post-apocalyptic begetting in order to repopulate the earth, Lalia offers a gendered twist on the biblical Abel's brother, Cain, by refusing to take part in the reproduction of patriarchal models of human society: as far as she can tell, the human lineage will end with her own extinction. The ultimate 'feminist killjoy' (to borrow Sara Ahmed's term (2017)), Lalia radically refuses to participate in human futurity if it means the replication of status quo gender and kinship relations.

Lalia's story does not end there, however: two more short stories, entitled 'La Incompleta' (2015) and 'La Esperada' (2019), deepen and complicate Rossi's preoccupation with extinction, reproduction and female agency, and what this means for the protagonist as well as for the future of humanity. 'La Incompleta' opens where 'Abel' leaves off: Lalia has just killed her own best hope for familial (and species) continuation while sea levels and global temperatures continue to rise. Feeling a sense of 'loneliness but not repentance,' Lalia decides to travel further south, this time to higher ground in Colombia in order to continue her search for other living beings. Here she finds two other survivors, Tami and Argos, and the three of them eventually form a kinship unit of sorts. Lalia is bewildered by the intense sexual attraction she begins to feel towards Argos, and she describes this as an entirely physical desire to 'sleep with him, have children with him.' Argos shows no interest in her sexual advances, however, telling her that they 'are not viable' in a reproductive sense. Lalia discovers that Tami and Argos are in fact 'parthogenic mutants,' male survivors who have biologically adapted to reproduce asexually. Interestingly, they still consider themselves to be male, but their penises are 'useless flaps, a reminiscence.' They explain that they are in the midst of an accelerated process of evolving from homo sapiens sapiens (a species that has proven to be cruel, self-interested and ultimately suicidal) into 'something more compassionate and intelligent.' Lalia calls this new species homo sapiens discriminans. Their asexual reproductive episodes have yet to result in viable descendants, however, and Tami describes his experiences of failed reproduction in monstrous terms, referring to his 'products' instead of babies or even offspring. Lalia is quick to point out to them that the feelings that they describe nausea, physical pain, emotional ambivalence - merely echo what women have experienced in childbirth for millennia. Claiming that he would rather die than go through that kind of pain again, Tami ingests artificial male hormones to stave off the reproductive episodes, and ultimately attempts suicide to permanently escape the ordeal. Despite Lalia's sexual advances toward him, Argos decides to venture off on his own, telling her, '[y] ou have desire, but I don't know if you are equipped for reproduction,' and 'if I see anyone like you, I will let you know,' which suggests that he is unable to conceive of physical desire or reproduction beyond a model of replication through the dyad of sexual difference.

As Postema (2008: 122) notes in his reading of La Loca de Gandoca, in many of Rossi's stories, 'male characters often adhere to the political power structures that maintain their authority'. Both Tami's and Argos' rejection of the possibility of alternative modes of species reproduction shows that even though these men claim to have 'evolved,' they are still incapable of envisioning or accepting a radical shift in sexual relations. Tami is unwilling to take on the pain of reproduction, while Argos is unable to enjoy an intimate relationship with Lalia without its being for reproductive purposes. Lalia empathises with Tami, recognising a parallel between his refusal to reproduce against his will and her murder of her brother, but at the same time she demonstrates a trust in nature that he does not share: against Tami's claim that 'nature is experimenting with me and it has no right,' Lalia thinks that nature 'knows' what it is doing by forcing a benevolent posthuman (that is, a post-homo sapiens sapiens) to

\footnotetext{
${ }^{5}$ It is significant that Rossi sets her story in the equatorial Americas: in contrast to the popular notion that human populations of the Americas came from the north, and across the Bering Strait, her human survivors move in a southward fashion, inviting a recovery of Indigenous knowledge systems that have been submerged, dominated, erased and/or overwritten.
} 
reproduce. She tells Tami that she will care for him and his 'products' as if they were her own family, but he is unwilling to participate in this alternative kinship scenario. Following Tami's botched suicide attempt and his subsequent plea for a mercy killing, Lalia runs away from his mutilated but still living form: even though she has no regrets about killing her own brother, Lalia demonstrates an outright refusal to kill this potentially post-human form of life.

In the final story, entitled 'La Esperada,' Lalia meets and falls in love with an Indigenous scientist called Andrés, who exhibits similar physical adaptations to the post-apocalyptic environment that Lalia has developed. He has been waiting for her arrival, he tells her, and they immediately engage in an intensely physical relationship. Even though Lalia has until now been convinced that she does not have a future in a reproductive sense, Andrés insists on their futurity as an underwater reproductive dyad: 'you and me and the sea,' he tells her (Rossi, 2019: 110). In a reversal of the Darwinian evolutionary narrative, in this story the future of humanity involves a return to the 'immense affinity' (Rossi, 2019: 118) of the ocean. However, despite his alignment with Indigenous worldviews, it quickly becomes apparent that Andrés is also a figure who remains aligned with power structures that maintain male authority. During their accelerated transformation into aquatic beings, Andrés begins tying Lalia up with rope so that she does not jump into the water prematurely and drown. When he eventually does untie her, Lalia notes wryly that it is because he has become too weak himself and not because she has asked him to do so (Rossi, 2019: 121). His reproduction of a violent act against a woman for 'her own good'-and perhaps more importantly, for the 'good' of species futurity —effectively crushes Lalia's libido: 'it was too much violence,' she says (Rossi, 2019: 120). Before their physical transformation is complete, the honeymoon between Andrés and Lalia comes to an end, and when Andrés' scientific calculations fail and he suffocates before he is able to transition to the watery environment, Lalia expresses indifference: 'he will die and I will leave him alone, and this species that we were, whatever it is called, won't be able to reproduce' (Rossi, 2019: 122). She does not feel 'sadness,' but instead wonders: 'who am I now? What was I turning into?' When she discovers that Andrés is unconscious but still alive she simply wonders whether, after their transformation into 'unrecognizable creatures' of the sea, they would still be a 'matable pair,' or whether 'she was going to return to the beginning of evolution' and 'end up as a bacteria or archaea' (Rossi, 2019: 122-123).

From her fratricidal refusal to reproduce the patriarchal status quo, to her refusal to kill Tami in order to welcome the possibly of posthuman life forms, to her indifference toward the possibility of species futurity with Andrés, Lalia's actions consistently resonate with Colebrook's idea of 'sexual indifference' — that is, 'the thought of production and "life" that does not take the form of the bounded organism reproducing itself through relation to its complement other' (2012: 167). Lalia's embracing of a sexually indifferent reproductive future also resonates with Elizabeth Grosz's (2008: 46) call for feminist re-appropriations of Darwin in order to develop a 'more politicized, radical, and far-reaching feminist understanding of matter, nature, biology, time, and becoming.' Colebrook (2008: 74) suggests that the Darwinian model of life is 'immediately radical,' since it precludes 'biological determinism' and confronts 'thought with the challenge to live up to the potentials for newness'. To be sure, the very concept of 'species' makes it 'appear as if sexual reproduction is the 'best' means of sustaining the existence of a life form,' when in fact 'earthly life forms actually engage in myriad forms of reproduction' and, 'in Darwinian terms, all species that manage to survive are equally successful' (Hird in Mitchell, 2015: n.p.). By displacing the primacy of sexual reproduction, space can be made for visions of futurity that move beyond 'our culture of rampant pronatalism,' and toward 'new possibilities that are neither hopeful nor nihilistic, but that take into account a sense of ongoingness through queering family structures and polyparenting' (Colebrook and Caroline, 2016: n.p.). These are precisely the kind of alternative kinship relations that Lalia herself attempts to imagine with Tami and his reproductive 'products.'

Submerged underwater in the final paragraph of the story, Lalia's last conscious thoughts are to wonder whether the sense of 'oneness' with the ocean that she feels is the result of physical adaptations, or whether it is merely the 'death trance' chemicals in her oxygen-starved brain tricking her into feeling Freud's oceanic 'infinite love' in the final moments before death (Rossi, 2013: 123). The very last line of the story reads: 'We stopped thinking. Or, we stopped existing' (Rossi, 2013: 123). That is, Lalia and Andrés have either stopped thinking (and, at least in a Cartesian vein, have therefore stopped being human, having mutated into something no longer fully human), or they have died and stopped existing altogether, which would also preclude their reproductive future as a species. Given anthropocentric anxieties around reproduction and sexual (in)difference - 'the lures and laziness that the sexual dyad as a figure has offered for thinking' (Colebrook, 2012: 167) — in the end it makes little difference. Whether one ceases to exist or merely ceases to exist as human, the end result is still a kind of human extinction.

Rossi's narrative engagement with human ends can be understood in terms of what Colebrook calls the 'thought experiment of extinction' (2014: 27), as a way to challenge gendered and hetero-normative conceptions of 'humanity,' and 'transform social norms and power structures that enforce inequalities of gender, sexuality, race and species' (Mitchell, 2015: n.p.). Rossi's feminist sci-fi stories engage with extinction in order to perform a radical critique of reproduction, while at the same time opening out to embrace non-binary possibilities of life. Taken 
together, the narrative arc of all three stories shows Lalia's body becoming increasingly 'marked with corporeal vestiges of humanity's nonhuman origins,' conjuring a simultaneously forward- and backward-facing subversion of 'teleological humanist discourses,' and evoking a 'new concept of humanity as undergoing a constant process of reconfiguration' (Coleman, 2016: 696). As Jane Bennett (2010: 121) suggests:

One can invoke bacteria colonies in human elbows to show how human subjects are themselves nonhuman, alien, outside vital materiality. One can note that the human immune system depends on parasitic helminth worms for its proper functioning or cite other instances of our cyborgization to show how human agency is always an assemblage of microbes, animals, plants, metals, chemicals, wordsounds, and the like.

As Rosi Braidotti suggests, ' $\mathrm{f}]$ ar from marking the rejection, extinction or the impoverishment of the human,' sitting with a discomforting vision of human extinction as a thought experiment might be 'a way of reconstituting the human' and re- 'negotiate who "we" are' (2019: 39). Instead of interpreting Rossi's speculative engagement with human extinction as a misanthropic death wish for humanity, perhaps we might see it as a 'disanthropocentric' (Cohen, 2015: 9) making way for visions of another kind.

As Jeffrey Cohen suggests, a 'not indifferent, not misanthropic, but disanthropocentric' dethroning of the human has the potential to make 'stories centered upon the human wobble, their trajectories veer' (2015: 25). This wobbliness is experienced in a particularly acute and discomforting way in Samantha Schweblin's eco-horror novella, Distancia de Rescate. ${ }^{6}$ The novella invites multiple readings: it is at once a psychological thriller about the ambivalent relationship between mothers and their young children; it is a supernatural story about the transmigration of souls; and it is a gothic, anti-pastoral example of what Gisela Heffes identifies as the 'rural turn' to non-urban spaces in Argentine novels of the second decade of the twenty-first century. This is a dynamic that reverses the modern mechanism where 'urban spaces constituted the key locus for rebuffing and cleansing the 'barbarity' deeply rooted in rural territories,' by drawing attention to the fact that 'the rural landscape is no longer untamed; rather, it has become (...) anthropogenically intervened, trimmed, exploited, and domesticated' (Heffes, 2019: 55-56). In other words, this novel unsettles reader expectations by transforming the green and idyllic space of the Argentine countryside into a twenty-first century agro-toxic nightmare. ${ }^{7}$

The narrative of Distancia de Rescate is structured as an unbroken dialogue between two voices, the first belonging to a woman (Amanda) who is immobile and confined to a hospital bed, and the second voice to a young boy (David), who kneels beside her and forces her to recount a series of recent events. Amanda does not seem to understand why she is unable to move, and David explains that, 'It's the worms. You have to be patient and wait. And while we wait, we have to find the exact moment when the worms come into being.' David's voice is insistent, claiming that 'It's very important, it's very important for us all' as he coaxes Amanda to piece together her memories carefully because: 'the exact point [of when the worms come into being] is in one detail, you have to be observant.' In this story, far from being an indicator of healthy, oxygenated, re/productive soil, the 'worms' that David refers to are of another sort altogether.

The text's central metaphor for care can be found in Amanda's preoccupation with what she calls 'rescue distance,' which is a constantly shifting calculation of how long it would take her to reach her daughter, Nina, in the event of an emergency. Amanda imagines herself attached to Nina by an invisible string or thread, which shortens or lengthens depending on the perceived immediacy of danger. Amanda reflects, 'I need to get ahead of anything that might happen,' and wonders, 'why do mothers do this?' As Ana María Mutis (2020: 44) notes: 'threads that tense, break, shorten or disappear lurk in the story as ominous symbols of the fragile bond that ties a mother to her child'. However, a mother's instinct to shelter her child at all costs is clearly not longer sufficient: as the narrative unfolds, we discover that David's mother, Carla, has also failed to protect her child from harm. Six years earlier, after her husband's stallion dies after drinking toxic water from a stream, Carla is horrified to realise that her toddler David has somehow been poisoned by the same water. Desperate for a solution in the absence of an adequate public health care system, Carla takes David to a community healer, who splits his spirit and migrates part of it to a healthy body, allowing part of an unknown spirit to enter David's body. After the procedure David is different: he survives, but he is cold and somehow empty, and he exhibits strange, repetitive behaviour. His skin

\footnotetext{
${ }^{6}$ Published in 2014, this novel was translated into English as Fever Dream and was nominated for the 2017 Man Booker International Prize. Samantha Schweblin herself was chosen by Granta magazine as one of the best Spanish-speaking writers under the age of thirty-five. Translations of the 2015 (non-paginated) Kindle edition are my own.

${ }^{7}$ I do not use the word 'nightmare' lightly here. The New Yorker reviewer, Lia Tolentino, described the novella as a 'sick thrill,' that is 'brilliantly structured and frightening' and 'belongs to the category of short, impressionistic novels best consumed in a single sitting' (and I would challenge anyone to try and not to read this story in a single sitting). Given the proliferation of ecological horror narratives provoking similarly 'visceral reactions' in recent years, we might begin to ask ourselves whether horror might be emerging as the genre for the Anthropocene.
} 
is covered in almost imperceptible blemishes and, according to Carla, he is no longer her son but has become a 'monster.'

Mutis reads Distancia de Rescate through its adherence to conventions of gothic fiction in order to elucidate the novel's ability to 'give visibility to invisible threats' (2020: 41). This occurs primarily through the figuration of the 'child monster that, through its connection to the eco-zombie, materializes the alienation that results from tampering with the environment' (Mutis, 2020: 55-51). The monstrous doublings resulting from the transmigrated souls of (interchangeable) children not only transforms the 'familiar into the uncanny to an intimate extreme,' but it also functions as a 'metaphor for pollution,' since the 'uncontrolled propagation of agrochemical poisons' is likened to 'the dispersion of souls invading foreign bodies' (Mutis, 2020: 42). The figure of the child offers a 'human scale to slow violence's temporal scale' (Cecire in Mutis, 2020: 50). In this way, the novel is able to evoke Nixon's 'slow violence' of environmental contamination, as effects that are dispersed over long periods of time, are not visible or newsworthy and are thus often not understood as violence per se.

Schweblin envisions an utter failure of maternal as well as societal care: as reviewer Manuel Allasino (2018: np) suggests, the novel 'follows a dizzying fatality always asking the same question: Is there any apocalypse other than personal?' (my translation). By the end of the story, Amanda is presumably dead, Carla has inexplicably disappeared, and their children (or what is left of them) are each placed in the ineffectual hands of their oblivious and - at least until the very last paragraphs - largely absent fathers. The tragic failure of Amanda and Carla to be able to protect their own children from harm says something crucial about the cultural link between practices of mothering and practices of ecological care. Mutis (2020: 43) suggests that employing the 'figure of the missing child' is not only a way 'to make the slow violence of agrochemical pollution visible and urgent,' but that it is also a way to 'politicize motherhood in order to advance an ecological message'. ${ }^{8}$ However, as Cate Sandilands (in Mitchell, 2015: n.p.) warns, essentialised notions of motherhood and care as a means of protecting future generations 'constrain women's political action to the private sphere of the family and inter-human interactions,' which in turn constrains 'women's sense of ethico-political agency in the face of the multi-species phenomenon (...) that is extinction'. Indeed, paralysed within her panicked space of maternal preoccupation, Amanda loses all capacity for meaningful action. The text's representation of these mothers' desperate yet ultimately futile efforts to protect their own children from danger reveals the misplaced nature of placing blame for failures of care in the private realm of the family, instead of explicitly identifying the very public risks to their well-being. In the case of this novel, this involves a catastrophic combination of agro-pharmaceutical regimes, late capitalist models of production, and a dangerous lack of public health protections. Repeatedly emphasising that the stakes are 'important for us all,' David tells Amanda that none of what has happened to him is his mother's fault: 'it is about something much worse,' he says. But the novella does not reveal what this something worse is. The entire narrative revolves around the impossibility of representation, the 'difficulty of saying the unsayable,' and just as Amanda is figuratively 'tied to a narrative that reaches no conclusion' (Mutis, 2020: 41), she is also literally trapped in her hospital bed - not to mention within her poisoned body — and unable to advance. Resonating with what Buell calls 'toxic discourse' Schweblin's novella underscores the idea that 'bodies ravaged by diseases (...) are also incapable of reproducing, hence aborting the idea of a future' (Heffes, 2019: 70).

The tendency to interpret this text primarily through a lens focused on fraught mother-child relations in the novel risks making us, as readers, guilty of David's repeated accusation of Amanda, that we are missing out on what is 'really important.' In this way, the story drags our anthropocentric tunnel-vision into the light of day by highlighting the problem of our only being able to really care about caring for that which is 'like' us. This is why I think it is useful to contrast the procreational models of maternal care in the novella to the kind of trans- or interspecies model of care that is modelled by David (and to a lesser extent, by Nina/David) at the end. In the transmigration of their souls both children are no longer the individual offspring of Amanda and Carla, but have transformed into something else, something plural, hybrid, something more-than-human. After his transformation, David begins to kill, mourn and bury the poisoned and moribund animals that seek him out. The model of care that he embodies is simply unintelligible to his mother, who is utterly horrified when he begins to help 'push' these dying creatures over the threshold into death, starting with ducks, but moving on to dogs, horses, and eventually Amanda herself. In his intimate kinship with these suffering souls, who are caught—as he himself is_-between the living and the dead, David becomes a monster to his mother. But even so, this careful (or care-full) act of 'pushing' demonstrates David's more-than-human level of compassion.

\footnotetext{
8 The politicisation of maternal loss is something that is familiar in the context of Argentina: the emergence of the Madres de la Plaza de Mayo, as a response to the rupture of maternal and kinship bonds that occurred during the Military dictatorship from 1976 to 1983, 'inserted the figure of the mother in the Argentine political sphere while modifying the place of enunciation of maternal discourse' (Domnigues in Mutis, 2020: 44). To be sure, in this novel, the notion that the child's soul is somehow 'elsewhere' but 'refuses to vanish completely shares with the desaparecidos its present absence and the uncertainty of its fate' (Mutis, 2020: 45).
} 
Juxtaposed to the imagined 'strings' of Amanda's rescue distance, in one of the final and most heartbreaking scenes of the novella we become aware of Nina/David's desperate attempts to literally hold their kinship networks (figured through the trope of family photographs) together with kitchen twine. In her study of 'speculative ethics in more than human life worlds,' Maria Puig de la Bellacasa (2017: 67) suggests that 'nothing holds together without relations of care'. David's solidarity with non-human animals illustrates a concern for the earth and all of the life forms that inhabit it. For Colebrook (2009: 250), 'only by thinking intensities beyond the human can we begin to live ethically', while Haraway (2003: 299) reminds us that, '[a]ctors, as well as actants, come in many and wonderful forms,' and 'reproduction' - or less inaccurately, the generation of novel forms - need not be imagined in the stodgy bipolar terms of hominids'. Taking a cue from David's more-than-human perspective, it might be possible to think about 'making kin' with monsters.

In his review of the novel, Carlos Pardo (2015) suggests that Distancia de Rescate invites us to re-think our 'imaginary of danger' because, by creating a subtle parallel between the planting of GMO soy crops and parental fears of physical and mental deformation of their offspring, the 'rescue distance' of the novella transforms into the vulnerable space of care for 'bourgeois humanism,' which involves 'a familiarity with a world that has already been lost' (my translation). To this I would add: even though we do not yet realise the extent to which what has been, and what is now in the process of being, is lost. Colebrook (2014: 26) suggests: 'the positing of the Anthropocene era relies on looking at our own world and imagining it as it will be when it has become past'. Tom Cohen (2016: 23) notes that even the very term Anthropocene already implies a kind of 'too-lateness,' since 'it can only anticipate or legitimize itself from a future recognition of it, after a disappearance it implies is accomplished'. Such temporal anxieties permeate Distancia de Rescate as well as Rossi's short stories: Lalia continually laments 'the usual theme, too late! It's always too late,' while Amanda is literally already as good as dead when David urges her to tie up the loose strings of her story. Amanda remains suspended in her narration, unable to move forward or backward, and David tells her: 'The important thing has already happened: what follows are the consequences.' 'Why do we continue the story then?' asks Amanda. 'Because you still do not understand,' he tells her. Like Lalia, Amanda is given a pill and told to take a nap. The narrative ends without her ever being able to make the connection between her death and the 'exact point' when the worms emerge, just as the narrative never directly mentions the real horrors that underpin it that is, the indiscriminate use of agrochemicals on GMO crops that is poisoning children in rural Argentina. ${ }^{9}$ Much like the zombie-like children with unexplained toxic deformities that populate Schweblin's novella, the ecological horrors can only ever haunt the margins of the narrative, never explicitly named. In this way, Schweblin holds up a funhouse mirror so that her readers might catch a terrifying (if fleeting and distorted) glimpse of the contemporary condition by placing us, as readers, into the baffled and desperate position of the protagonist. Like Amanda, we are never fully able to put the fragments of the story back together. At one point, one of the mothers in the story muses, 'the fears that move us are not the ones that we should actually be afraid of.' Also like Amanda, we as readers remain largely unable to understand the full extent of species loss and environmental destruction that we have brought upon ourselves, and thus we are easily manipulated into caring deeply about matters that seem important, but that in fact merely distract us from caring about the things which are really 'important for us all,' as David's more-than-human ethics of care would suggest.

Ultimately, neither Distancia de Rescate nor 'Abel' shies away from unhappy endings in the interest of narrative closure: on the contrary, ambiguous and potentially discomforting, they invite readers to rethink questions of ethical responsibility by embracing the specifically negative potential in Anthropocene fictions. Schweblin's monstrously double, non-individuated children and Rossi's porously amphibious and no-longer-fully-human narrator resonate with Stacy Alaimo's (2018: 435-436) theory of 'trans-corporeality,' which 'means that all creatures, as embodied beings, are intermeshed with the dynamic, material world, which crosses through them, transforms them, and is transformed by them,' and thus contesting 'the master subject of Western humanist individualism, who imagines himself as transcendent, disembodied and removed from the world he surveys'. In the case of Schweblin's children, these trans-corporeal processes are, quite literally, fatal, but each of these stories hints at the possibility of another kind of relationship between humans and their world. This relationship might be understood through Karen Barad's sense of 'intra-action,' where things are not ordained in a subject-object relationship (where one subsumes the other) but, instead, are open to action among things through relationality and ontological equality. As Haraway (2003: 298) suggests, 'nature is made, but not entirely by humans; it is a co-construction among humans and non-humans'.

Haraway (2003: 327) also reminds us that it is 'not a 'happy ending' we need, but a non-ending. That is why none of the narratives of masculinist, patriarchal apocalypses will do'. I have suggested that Rossi and Schweblin's open-ended narrative engagements with human 'ends' can help us to keep Braidotti's (2013: 86) question — 'who is this 'we' whose humanity is at stake?' - at the forefront of our minds. As Serenella Iovino (2018: 115) suggests,

\footnotetext{
${ }^{9}$ As Mutis (2020: 39) points out: 'the nightmare of ecocide that the novel depicts can be traced back to 1996, the year Monsanto's genetically modified soy was approved in Argentina as an integral part of a new model of agriculture,' spiking the 'production of transgenic soy and, consequently, the use of glyphosate'.
} 
in 'our 'post- geological' epoch — call it Anthropocene, Plantationocene or Capitalocene' - the idea of decentring Anthropos 'means to literally swerve our priorities, liberating the world's bodily natures from the discursive — and material — delusions of human-centred narratives'. The 'mark of posthumanism,' suggests Sheryl Vint (2007: 175), rests in an 'openness to change and newness, to becoming other and giving up on old categories when they no longer serve rather than defending them against inevitable change'. Contemplating the demise of homo sapiens forces one to think about what other kinds of life forms might evolve from, or instead of, 'humanity' as we know it' (Mitchell, 2015: n.p.). Thus, Rossi's highlighting of figural human extinction and Schweblin's more-than-human model of care can be read as invitations to imagine new and 'nonexploitative' forms of human and non-human 'togetherness' (Puig de la Bellacasa, 2017: 240) in a move toward what Braidotti (2013: 81) calls a 'planetary geocentered perspective'. Providing an imaginative space beyond the logic of hu/man exceptionalism, these narratives invite readers to understand that somewhere between the temporal 'too lateness' of Anthropogenic culpability, and the 'not yet-ness' of possible futures, there may still be spaces for alternative narratives of care and futurity to emerge.

\section{REFERENCES}

Ahmed. S. (2017). Living a Feminist Life. Durham and London: Duke University Press. https://doi.org/10.1515/9780822373377

Alaimo, S. (2018). Trans-Corporeality, in R. Braidotti and M. Hlavajova (eds), The Posthuman Glossary (pp. 435-428). London and New York: Bloomsbury.

Allasino, M. (2018). Distancia de Rescate, el hilo vital que nos une a nuestros hijos. La Tinta. https://latinta.com.ar/2018/03/distancia-rescate-hilo-vital-nos-une-hijos/. (Accessed 7 May 2019).

Barad, K. (2003). Posthumanist Performativity: Toward an Understanding of How Matter Comes to Matter. Signs: Journal of Women in Culture and Society, 28(3), 802-831. https:/ / doi.org/10.1086/345321

Bennett, J. (2010). Vibrant Matter: A political ecology of things, Durham and London: Duke University Press. https://doi.org/10.1215/9780822391623

Braidotti, R. (2019). Posthuman Knowledge. Cambridge: Polity Press.

Canavan, G. (2014). 'If the Engine Ever Stops, We'd All Die': Snowpiercer and Necrofuturism. Paradoxa, 26. https://epublications.marquette.edu/english_fac/298. (Accessed 3 February 2021).

Cohen, J. (2015). Stone: An Ecology of the Inbuman. Minneapolis: University of Minnesota Press. https://doi.org/10.5749/minnesota/9780816692576.001.0001

Cohen, T. (2016). Trolling 'Anthropos' or, Requiem for a Failed Prosopopeia, in T. Cohen, C. Colebrook and J. Hillis Miller (eds), Twilight of the Anthropocene Idols (pp. 20-80). London: Open Humanities Press. https://doi.org/10.26530/OAPEN_588463

Colebrook, C. (2008). On Not Becoming Man: The Materialist Politics of Unactualized Potential, in S. Alaimo and S. Heckman (eds), Material Feminisms (pp. 52-84). Bloomington and Indianapolis: Indiana University Press.

Colebrook, C. (2009). On the Very Possibility of Queer Theory, in C. Nigianni and Merl Storr (eds), Deleuze and Queer Theory (pp. 11-23). Edinburgh: Edinburg University Press. https://doi.org/10.3366/edinburgh/9780748634040.003.0001

Colebrook, C. (2012). Sexual Indifference, in T. Cohen (ed.), Telemorphosis: Theory in the era of climate change (Vol. 1) (pp. 167-182). Ann Arbor: Open Humanities Press.

Colebrook, C. (2014). Death of the Posthuman: Essays on extinction (Vol. 1). University of Michigan Library: Open Humanities Press. https://doi.org/10.3998/ohp.12329362.0001.001

Colebrook, C. and Caroline, J. (2016). Interview. The Brooklyn Rail. https://brooklynrail.org/2016/09/art_books/claire-colebrook-with-jessica-caroline. (Accessed 1 June 2020).

Coleman, V. (2016). Becoming a Fish: Trans-Species Beings in Narrative Fiction of the Southern Cone. ISLE: Interdisciplinary Studies in Literature and Environment, 23(4), 694-710. https://doi.org/10.1093/isle/isw073

Edelman, L. (2004). No Future: Queer theory and the death drive. Durham: Duke University Press. https://doi.org/10.1215/9780822385981

Estok, S. (2009). Theorizing in a Space of Ambivalent Openness: Ecocriticism and Ecophobia. ISLE: Interdisciplinary Studies in Literature and Environment, 16(2), 1-23. https://doi.org/10.1093/isle/isp010

Grosz, E. (2008). Darwin and Feminism: Preliminary Investigations for a Possible Alliance, in S. Alaimo and S. Heckman (eds), Material Feminisms (pp. 23-51). Bloomington and Indianapolis: Indiana University Press.

Haraway, D. (2003). The Promises of Monsters: A Regenerative Politics for Inappropriate/d Others, in J. A. Weinstock (ed), The Monster Theory Reader (pp. 459-521). Minneapolis: University of Minnesota Press. https://doi.org/10.5749/j.ctvtv937f.27

Haraway, D. (2007). When Species Meet. Minneapolis: University of Minnesota Press. 
Haraway, D. (2015). Anthropocene, Capitalocene, Plantationocene, Chthulucene: Making Kin. Environmental Humanities, 6, 159-165. https://doi.org/10.1215/22011919-3615934

Heffes, G. (2019). Toxic Nature in Contemporary Argentine Narratives: Contaminated Bodies and Ecomutations, in I. Kressner, A. M. Mutis and E. M. Pettinaroli (eds), Ecofictions, Ecorealities and Slow Violence in Latin America and the Latinx World (pp. 55-73). Abingdon, UK: Routledge. https://doi.org/10.4324/9781003001775-3

Hunt, E. (2019). BirthStrikers: Meet the Women Who Refuse to Have Children until Climate Change Ends. The Guardian. March 12. https://www.theguardian.com/lifeandstyle/2019/mar/12/birthstrikers-meet-thewomen-who-refuse-to-have-children-until-climate-change-ends. (Accessed 7 May 2019).

Iovino, S. (2018). (Material) Ecocriticism, in R. Braidotti and M. Hlavajova (eds), The Posthuman Glossary (pp.112-115). London and New York: Bloomsbury.

Iovino, S. and Oppermann, S. (2012). Material Ecocriticism: Materiality, Agency, and Models of Narrativity. Ecozon@ European Journal of Literature Culture and Environment, 3(1), 75-91. https://doi.org/10.37536/ECOZONA.2012.3.1.452

Johns-Putra, A. (2014). Care, Gender and the Climate Changed Future: Maggie Gee's The Ice People, in G. Canavan and K. S. Robinson (eds), Green Planets: Ecology and science fiction, (pp. 127-142). Middleton: Wesleyan University Press.

Johns-Putra, A. (2016). 'My Job is to Take Care of You': Climate Change, Humanity, and Cormac McCarthy's The Road. MFS: Modern Fiction Studies, 62(3), 519-540. https://doi.org/10.1353/mfs.2016.0041

Kearns, S. (2016). Widening the Spectrum of Desire and Nation: Anacristina Rossi's Fiction. QED: A Journal in GLBTQ Worldmaking, 3(2), 93-106. https://doi.org/10.14321/qed.3.2.0093

Merola, N. M. (2018). Juliana Spahr and Anthropocene anxiety, in K. Bladow and J. Ladino (eds), Affective Ecocriticism: Emotion, embodiment, environment (pp. 25-64). Lincoln and London: University of Nebraska Press. https://doi.org/10.2307/j.ctv75d0g8.6

Mitchell, A. (2015). Gendering Extinction. Worldly wordpress.com. (Accessed 20 April 2019).

Mutis, A. M. (2020). Monsters and Agrotoxins: The Environmental Gothic in Samantha Schweblin's Distancia de Rescate, in I. Kressner, A. M. Mutis and E. Pettinaroli (eds), Ecofictions, Ecorealities and Slow Violence in Latin American and the Latinx World (pp. 39-54). New York and London: Routledge.

Pardo, C. (2015). Los Hijos Tóxicos: Critica de Distancia de Rescate. El Pais Cultura. 7 March. https://elpais.com/cultura/2015/03/05/babelia/1425551789_495804.html. (Accessed 20 April 2019).

Postema, J. (2008). Ecology and Ethnicityisêpin Anacristina Rossi's La Loca de Gandoca. Cincinnati Romance Review, 27, 113-24.

Puig de la Bellacasa, M. (2017). Matters of Care: Speculative ethics in more than human worlds. Minneapolis: University of Minnesota Press.

Rossi, A. (2013). Abel, in Lunas en Vez de Sombras y Otros Relatos de Ciencia Ficción (n.p.). San José: EUNED.

Rossi, A. (2015). La Incompleta, in Te Voy a Recordar, Relatos de Ciencia Ficción (n.p.). San José: EUNED.

Rossi, A. (2019). La Esperada, in Protocolo Roslin y Otros Relatos de Ciencia Ficción (pp. 107-123). San José: Editorial Costa Rica.

Schweblin, S. (2015) Distancia de Rescate. Manhattan: Random House (Kindle Edition).

Tolentino, L. (2017). The Sick Thrill of Fever Dream. The New Yorker. https://www.newyorker.com/books/page-turner/the-sick-thrill-of-fever-dream. (Accessed 1 February 2020).

Trexler, A. (2015). Anthropocene Fictions: The novel in a time of climate change. Charlottesville and London: University of Virginia Press.

Vint, S. (2007). Bodies of Tomorrow: Technology, subjectivity, science fiction. Toronto: University of Toronto Press. https://doi.org/10.3138/9781442684072

Citation: Mackey, A. E. (2021). Reproduction Beyond Hu/Man Extinction: Detoxifying Care in Latin American Anthropocene Fictions. Feminist Encounters: A Journal of Critical Studies in Culture and Politics, 5(1), 06. https://doi.org/10.20897/femenc/9743

Copyright (C) 2021 by Author/s and Licensed by Lectito BV, Netherlands. This is an open access article distributed under the Creative Commons Attribution License which permits unrestricted use, distribution, and reproduction in any medium, provided the original work is properly cited. 